\title{
Fixed Investment and Economic Growth: ARDL and Causality Exploration for SADC Countries
}

\author{
Reginald Masimba Mbona \\ School of Economics and Finance, Jiangsu University \\ No. 301 Xuefu Road, Zhenjiang, Jiangsu, P.R. China \\ E-mail: rmmbona@yahoo.com
}

Chilombo Stephania Mumba

Internal Auditor at Ministry of Finance, No. 50062 Chimanga Road, Lusaka, Zambia

E-mail: stefmumba8@gmail.com

Tinashe Mangudhla (Corresponding author)

School of Economics and Finance, Jiangsu University, P.R. China

E-mail: tmangudhla@gmail.com

Received: May 21, 2021 Accepted: July 17, $2021 \quad$ Published: October 25, 2021

doi:10.5296/ber.v11i4.18659 URL: https://doi.org/10.5296/ber.v11i4.18659

\begin{abstract}
In assessing the short run and the long-run effects of fixed investment and economic growth among Southern Africa countries, we evaluated the economic progress of the SADC (Southern African Development Committee) region. Our objective is to determine how variables (GDP, purchasing power parity, inflation, electricity, balance-of-payments, and unemployment) can be affected by the fixed investment. In determining how fixed investment affects economic activities and policies among the states, the ADRL estimation approach is applied. Using data from 13 countries in the SADC region from the period 1992-2018, we enumerate the variables' marginal returns against the fixed investment component. The results of diagnostic and other tests show that all statistical procedures are robust. The result proves that the benefits of fixed investment are yielded over a long period rather than short periods. As a result, the cost in the short term cannot be compared to the benefits that will be enjoyed later by an economy as it becomes productive. Furthermore, the
\end{abstract}


lack of consistent fixed investment among countries will eventually lead to insufficient cash flow, which will negatively affect the currency. These results would seem to suggest that the introduction of policies that promote investment will massively contribute to increased productivity and positive economic growth in the region.

Keywords: Fixed investment, Economic growth, Southern Africa, Inflation, ADRL model

\section{Introduction}

Governments have been working hard to ensure that they keep very high levels of investment so that their economies can sustain the growing population demands. Besides creating technologies through the building of assets and infrastructure development, one of the main benefits of investment is employment creation. On top of that, increased investment results in higher incomes for registered workers, which gives better living standards. In pursuit of this, economic blocks and treaties that encourage economic growth have become more formalized. These include blocks like SADC, European Union, ECOWAS. The countries in one block work together to help each other promote economic activities, including fixed investment. Also, they work together to create an investment-friendly environment while at the same time tackling socio-political challenges together.

This paper aims to examine how fixed investment has affected economic growth both in the short and long run for the Southern Africa Development Committee (SADC), which is a block of countries located on the southern part of the African continent. According to (Mupimpila and Funjika, 2010), the region considers integration a channel to enhance development; hence, they keep striving to improve their economies. One of the indicators that they use to monitor regional performance is fixed investment or fixed capital accumulation. Examining whether the economies are efficient in the use of the available investments is a research area that is still lagging; hence this study aims to fill that gap. Using GDP as a measure for economic growth, this paper investigates how the region has benefited from the investments injected into the economies. The study is done for 25 years with the following main objectives:

$>$ To examine the effect of fixed investment on short term economic growth

$>$ To assess the impact of fixed investment on long term economic growth

$>$ To evaluate how the other control variables are affected by fixed investment in the short and long run.

There are several critical key areas where this study makes an original contribution. Firstly, this study puts together all the sources of investment (FDI and local investment) for the SADC region after they have been converted into usable assets being used in production (Vinesh et al., 2014). In addition to that, several small-medium enterprises operate mostly as sole traders or partnerships that have been making a significant contribution to investment, especially in the mining and agriculture sectors. Hence, fixed investments incorporate them into the overall contribution.

Again, this study offers some essential insights into a region that has been working 
tremendously to attract investment and boost its capital growth. The paper is of help to policymakers as they design policies with knowledge on the factors that can affect investment. Since the region is also heavily dependent on external debt to finance, its budgets different lenders would know if the governments have reasonable investment efficiency that can, later on, generate funds to pay back the loans. As SADC seeks to improve its regional investment integration as noted in their investment protocol of 2001, all nations must integrate into coming up with policies that favor investment in their interdepend economies.

Similarly, individuals and organizations looking forward to investing in SADC can use our results as a reference and decision-making since our study considered some of the factors that need to be considered before engaging in business. The fact that past papers focused most on FDI, this paper is also advocating for the independence of economies. It also includes domestic investment so that the economies rely less on foreign investment, which was also highlighted by (Yang and Stone, 1985). Finally, the study also aims to add literature on factors affecting economic growth, focusing on fixed investment.

The rest of the paper is structured as follows: background of fixed investment, literature review, methodology, presentation and discussion of results, and then the conclusion.

\subsection{Background of Investment}

A comprehensive generalized definition by (Anwer \& Sampath, 1999) states that "Investment refers to all economic activity that involves using resources to produce goods and services." Through fixed capital formation, there is a creation of fixed assets that include buildings, roads, equipment, and various infrastructure used in production. It also consists of the amount spent on research and development, which is responsible for the creation of new products and production methods. The benefits of investment growth mainly include improvement in economic growth (Baliyan \& Jain, 2016), increased innovation through the introduction of technologies borrowed from other places (Barro, 1991), creation of employment (Vinesh et al., 2014), and also to better living standards for the people through wealth creation.

According to studies by (Baliyan \& Jain, 2016; Sharma \&Abekah, 2007), capital can be injected into the economy as domestic and foreign capital; then, it is used to create the fixed assets in the economy. Foreign direct investment (FDI) has been subject to many studies, including (Yang \& Stone, 1985; Stefanović, 2008; Pelinescu \& Radulescu, 2009; Nyarota et al., 2012; Carlos \& Rowland, 2004). It contributes either directly through inflows of capital or indirectly through spillovers to other parts of the economy from the investments made. The domestic side of the capital comes in the form of either private capital from business start-ups by locals or investments into existing businesses, or it also comes from government expenditure directly through public investment as reported by (Afonso \& St. Aubyn, 2018); and, indirectly through their various state-owned enterprises. Of these sources of capital, (Kosma, 2015; Bayraktar, 2018) concluded that private investments are more efficient and productive compared to those owned by the state. This is very true for SADC countries where corruption within government systems is very high.

Although fixed investment growth has been steady, most of the countries have failed to 
maintain their expected growth levels compared to other developing regions. The region looks less aggressive in their investment, which this study investigates to assess if it affects economic growth. The countries in the SADC region continue to lag behind the world average as well as fellow developing economies in their level of fixed investment growth. The inconsistencies in the economies that are dependent on each other, with South Africa as the most influential, have been the main factor behind the low investment, with some investors pulling out their investments.

Even though SADC is very rich in natural resources, including gold, oil, diamond, copper, lithium, and land, it has still been attracted to fully enjoy the benefits from these due to inadequate capital investment. According to (Bello \& Osinubi, 2016), unless a conducive investment environment backs resources, there will not benefit the economy. They added that efficiency in the use of these resources further determines their impact on the economy, which was also supported by (Amir et al., 2012).

\subsection{Fixed Investment in SADC}

SADC is an intergovernmental organization which is was formed to encourage sustainable development, economic growth, socio-economic growth, and political integration of the member states (Mbulawa, 2015). Unlike other regions (Vanheukelom \& Bertelsmann-Scott, 2016), the region is built on a win-win situation as they prioritize only those sectors with clear mutual regional benefits. It is made up of 15 member states, South Africa, Namibia, Botswana, Mauritius, Swaziland, Madagascar, Malawi, Mozambique, Tanzania and Zambia, Democratic Republic of Congo (DRC), Zimbabwe, and Angola. Based on a report on the SADC website, the region has accumulated a GDP of US $\$ 471.1$ billion with a population of 257.7 million since its official signing in 1992. In their study (Mupimpila \& Funjika, 2010) also noted that the integration of the region requires all members to be stable as countries increase the chances of transmitting instability. The effect is higher when the region has stronger relations and the number of sectors they share in common.

According to their regional indicative strategic development plan (RISDP), cited by (Mbulawa, 2015; Vanheukelom \& Bertelsmann-Scott, 2016), SADC aims to achieve its goals on economic and non-economic development by 2020 was still lagging behind the scheduled time frame. The main areas of focus in this strategic plan included trade amongst member states to enhance their foreign currency reserves, increase the value of their produce from the primary industry, which will move their economies at least to the secondary sector, finance development which promotes the activities in borrowing and lending to promote investment, savings and wealth growth and investment through increased in financial and capital markets strengths to boost both foreign and local investment. Success has been noted in free trade as at least more than two-thirds of the members joined the free trade zone and integrated the financial markets, but the investment is still lagging (Vinesh et al., 2014; Vanheukelom \& Bertelsmann-Scott, 2016).

The level of investment has been declining as the region has not been favorable for foreign investment and domestic investments, which is one major reason why the finance and investment protocol was signed in 2006 as a countermeasure. The protocol mainly covers 
issues on investment promotion agencies in each country, which was done by all states, investment regimes as a database of all the investment policies in the country, domestic and intra-SADC investment, which encouraged regional cooperation in investment, and finally, tax cooperation to create favorable investment environment for companies.

Furthermore, the region has also been implementing a free trade zone, and they are also seeking financial markets integration to boost inter-country investments and exchange of capital goods. Also, they have been working on improving the transport and telecoms infrastructure, which is a key investment needed in propelling further connectivity within the region.

The secretarial reports noted that the region has been failing to meet its expected investment GDP percentage. The majority of the countries remain far from the target with countries like Zimbabwe, which is not included in this study due to missing data and is still expected to decline in investment. Thus, this study will therefore assess how much these factors have affected the economic growth of the whole region.

\section{Literature Review}

(Kwan et al., 1999) their study on investment growth in China found that fixed investment or fixed capital accumulation was key in the country's economic growth. However, they also noted that this subject had not been examined in literature as most studies use growth estimates to analyze the factors. This is also observed for SADC, which is one reason why this study is of great importance to the region.

In a case study on the factors that affect investment in Bangladesh (Amir et al., 2012) clearly states that "Economic wisdom of investment of economics enumerates that there has been a causal nexus between investment and other macroeconomic variables." This means that factors like inflation, GDP, interest rate, and foreign currency exchange which they used as dependent variables, are all affected by investment in the country. This notion was seconded by (Kosma, 2015) in his case study on Greece. Both studies find a positive relationship between fixed capital and GDP, something to be investigated for SADC. Kosma used taxation and credit growth as other variables that have a significant negative effect on investment growth.

Another school of thought by (Blomstrom, 1996; Kwan et al., 1999) argued that capital formation does not determine the level of GDP growth; but rather, it is expected that rapid economic growth leads in the long run to higher fixed capital growth. They argue that growth precedes investment because growth shows the likelihood of returns in the economy and increased opportunities. (Anwer \& Sampath, 1999) in finding the long term relationship between capital formation and GDP, added that economic growth leads to the consumption and demand for capital goods. This means that higher economic growth percentage change leads to a demand push increase in capital to sustain the growth as well as to supply the ready market. Because of this mixed result, this study investigates the relationship between these two using fixed investment as the dependent variable, which is influenced by economic growth and the other variables. 
To further support our use of total capital formation, a study by (Cavallo et al., 2017) found that several countries were receiving significant investment contributions from private inflows of capital from outside the respected countries. This is very true for SADC, where workers migrate outside the region to look for better living conditions, explore new careers, and run away from the high cost of living, which is worsened by harsh economic environments. The capital comes in the form of remittances, fixed assets, equipment, and other technologies that are used in production.

Another investment tool is the governments' public investment to increase output to a certain level. (Rabnawaz \& Jafar, 2016; Kosma, 2015; Bayraktar, 2018) concluded that growth in GDP would also result in a rise in public investment. Public investment is mainly in the construction and other strategic industries that are dominantly controlled by the state in the region. (Bayraktar, 2018) adds that there is a need for reduced volatility for the public investment to yield expected results as well as for its impact to be consistent on the economic growth.

Regional integration has been one of the main focuses of the SADC agenda (Mupimpila \& Funjika, 2010). Most studies like (Ali et al., 2018; Nyarota et al., 2012) for SADC and (Nangpiire et al., 2018; Willem te Velde et al., 2004) for the Sub Sahara region focus mainly on FDI; but seem not to consider how this is benefitting the economy when it is now in its usable state. However, an inconsistent flow of FDI has seen the region remain lagging in total investments.

In other investment integration (Ruwaydah \& Ushad, 2015) examined how the stock market affects economic growth. In their results, they found that there is a solid relationship between stock market development and economic growth. This means that the region seeks to liberate stock markets to build a more substantial investment base.

Cross-border trading has been very common within the region (Nangpiire et al., 2018). In a study carried by (Mutambara, 2008) integration in trade was seen as one of the promoters of investment. This creates markets for goods and promotes retailer business, which is very common amongst small businesses. Trade also allows the sharing of technologies within the region, enabling the growth of and creating companies in different industries. To add to trade, transport integration is key to ensuring a smooth movement within the region, mainly connected by road and railway networks.

As stated earlier on the studies that assess fixed investment and economic growth are still very limited. Hence, this study will be of great significance to SADC as it pushes its growth. With studies that have been done so far having mixed conclusions, it is essential to assess the region independently.

\section{Methodology}

\subsection{Data Source and Type}

The study uses data from 1992 to 2018 for 13 countries in the Southern African region as obtained from World Bank Development Indicators. The period used is long enough to 
observe trends over a long period in how as well as accounting for the short-term effect. The study uses secondary data as not all the government agencies of these countries have not provided sufficient data to be used for such a study.

\subsection{Time of Study}

The period is long enough to avoid the effect of economic cycles on our results. Secondly, we used the whole period to find if there are any differences in how these factors affect investment in the long run and the short run. The main aim of this is to determine how the variables used can be affected by different policies and activities in the economy based on their effects on investment over time by checking for their marginal returns.

The period was chosen because all data needed for the variable were available for the countries being used in the study. The challenge we faced was that not all countries had data available, which resulted in some of them being excluded from the study, as also reported by (Ruwaydah \& Ushad, 2015) in a survey of the block's GDP growth. Zimbabwe was omitted, as has also been done in SADC reports for 2006-2007 due to limited data. We also excluded it because it is an outlier due to its high figures for variables like inflation, which was over a million high.

\subsection{The Variables}

Even though six variables were used, they remain inexhaustive of the factors that affect investment, and at the same time, we also have differences within countries. These factors include transport, degree of corruption, political stability, government efficiency, affecting our results. To deal with this bias, we also had country dummies to remain only with time-series variations of the variables being explained (Blomstrom, 1996). The variables used in this study include Fixed Investment, GDP, Purchasing Power Parity (PPP), Inflation rate, Balance of payment, Electricity, and Unemployment rate.

\subsubsection{Investment/ Gross Capital Formation (\% of GDP)}

This combines fixed assets addition, replacement, and building in the economy and net inventory changes (Encinas-Ferrer \& Villegas-Zermeño, 2018). The assets include infrastructure, equipment, and machinery additions. The stock takes into account all the unfinished goods and also the buffer inventories kept by companies. An increase in these are a form of investment and also create platforms for further investment and growth. For example, an investment in building shopping malls creates an opportunity for retailers to invest in stores. A high capital formation is a key to building a stable economy as it affects all the primary arms of the economy, which are households, government, and corporations.

\subsubsection{Gross Domestic Product}

GDP is one of the most critical indicators of activity level within the economy as it measures the output growth within the economy (Kosma, 2015; Yang \& Stone, 1985). The positive rate at which output growth changes reflect the efficiency and productivity in the market gives a high motivation for investment (Vinesh et al., 2014). According to (Blomstrom, 1996) high economic growth is expected to attract investment and increase investment in the country. 
Investment in this study is working as the input that is needed to steer up economic growth, which is the output. The study is therefore investigating the interaction between these two key variables.

\subsubsection{Inflation}

Inflation is measured by the percentage change in the consumer price index. The cost is made up of the average price of purchasing a set of basic commodities for households. According to (Willem te Velde et al., 2004), a lower or reduced inflation positively affects investment formation. It is also expected that when there is a higher economic activity that is measured by investment, there is lower inflation as the economy will be functioning well. Inflation remains a significant concern not only for the region but for the rest of the world. Hence, we picked inflation as one of the control variables.

\subsubsection{Electricity}

This is the percentage of people in the population with access to electricity. In modern days most of the investment in businesses, industries, and stores needs energy in one way or the other. It is expected that an adequate and reliable electricity supply which is a fixed investment, will also lead to improved economic development, which in turn encourages investment (Vanheukelom \& Bertelsmann-Scott, 2016). The energy sector is considered as one of the primary needs for any economy in this modern age; therefore, there is a need for high investment in this sector.

\subsubsection{Employment}

These are workers in the economy who work under formal contracts, formalized orally or in written form with their wages not affected by their company's revenue. This is an essential measure as it looks at how formal the investments are, especially in a region with a lot of informal business and self-employed people in different sectors. Additionally, it also gives a record of formal employment, which we cannot find accurate data on in most countries in the region (Baliyan \& Jain, 2016). Thus, fixed Investment can create high employment in the economy and is expected to give a positive boost, especially in the short term, unless it is sustained over a more extended period.

\subsubsection{Purchasing Power Parity Conversion Factor, GDP}

To measure the currency's strength, we used this variable which calculates the amount of local currency required to purchase the same amount of goods and services using the US dollar in the US market. Using this approach instead of exchange helps to find the standardized value of each currency to the US dollar, which is also the commonly used currency for trade within the region. It is also known that investment stabilizes the economy. Hence, as investment increases, it is expected that the currency of the country also becomes stable. Since we are using different economies, it is significant to consider the strength of their currency in the assessment. 


\subsubsection{Balance of Payment}

The balance of payment (BOP) summarizes all transactions that a country's individuals, companies, and government bodies complete with individuals, companies, and government bodies outside the country. These transactions consist of imports and exports of goods, services, capital, and transfer payments, such as foreign aid and remittances. When the investment is high, it is expected that it will boost industrial production and output, which will, in turn, increase the ability to support the market domestically while, at the same time, growing exports which will then result in a favorable BOP.

\subsection{Estimation Procedure}

In testing the relationship between fixed investment (which is our dependent variable) and the independent variables, we applied the Autoregressive Distributed Lag Model (ARDL). The model was developed by (Pesaran et al., 2001) as a model that will capture the long-run dynamics while at the same time keeping the short-term dynamics. This means that short-term factors like economic cycles and changes associated with the region's leadership do not affect the outcome of this study.

The use of this model is in line with authors like (Nyarota et al., 2012; Ruwaydah \& Ushad, 2015; Ali et al., 2018), who argue that there is a need to consider short term factors as they also affect our results in the long run and ADRL has proved to be a useful tool for such cases. Additionally, the model also deals with serial correlation and endogeneity issues, which makes it reliable and significant in testing for the relationships. The substantial assumptions and conditions for applying the model for estimation were all taken into consideration, and our data was fit for this estimation. Thus, the data for the 13 SADC countries fulfilled the analysis requirements and later was then run through STATA 16 software to come up with the results presented.

The function utilized in this model will encompass fixed investment which is the dependent variable to test for the linear relationship imploring various economic variables to test for output growth in the SADC region.

$$
F I=f(Y, P P R, I, B O P, E L, E M)
$$

Where FI = Fixed Investment; Y = annual GDP; PPR = purchasing power parity rate; I = annual inflation rate; $\mathrm{BOP}=$ balance of payment; $\mathrm{EL}=$ Electricity availability; $\mathrm{EM}=$ unemployment rate

\subsubsection{Panel First and Second-generation Unit Root Tests}

When imploring the ARDL model, the variables must have an order of integration less than 2. Therefore, it is essential to carry out the panel unit root test to determine if the variables are suitable for the model; otherwise, we remove them from the study. To examine the presence of the unit root test, the IPS and LLC unit root tests are used. (Im, Pesaran, \& Shin, 2003; Levin, Lin \& Chu, 2002) respectively proposed these tests. The ADF regression for these tests is as follows: 


$$
\Delta y_{i t}=\gamma_{i} y_{i, t-1}+\sum_{j=1}^{P} \varphi_{j} \Delta y_{i, t-j}+\varepsilon_{i t}, \text { Where } \gamma_{i}=\rho_{i-1}
$$

These test gauge the hypothesis $H_{0}: \gamma_{i}=0 \quad\left(\rho_{i}=0\right)$ against the other option of stationarity $H_{1}: \gamma_{i}<0\left(\rho_{i}<1\right)$. However, these tests are known as first-generation unit root tests. They are preferred to the second generational unit root tests such as Pesaran's cross-sectional Augmented Dickey-Fuller (CADF) and the CIPS test when a cross-sectional reliance exists among the regressors. We then start by utilizing the cross-section dependence (CD) test invented by (Pesaran, 2004). This test is implored to ascertain whether the panel data has cross-sectional reliance. Then the panel unit root tests are carried out to ensure that all the variables of interest are either I (0) or I (1), respectively.

\subsubsection{Panel Co-integration Test}

Attesting to the order of integration of the variables, the author then makes use of the Pedroni panel co-integration test, (Pedroni 1999; Pedroni 2004). The Pedroni co-integration test the null hypothesis of no co-integration against the alternative of co-integration:

$$
y_{i t}=x_{i t}^{\prime} \beta_{i}+z_{i t}^{\prime} \tau_{i}+e_{i t}
$$

Where for each panel $i$, the covariates in $x_{i t}$ is an, I (1) arrangement, and these tests require the covariates to not be coordinated among themselves. The Pedroni test takes into account panel explicit co-integrating vectors, and such heterogeneity differentiates it from the Kao co-integration test. This is the reason why the Pedroni test was preferred to the Kao co-integration test.

\subsubsection{Panel Autoregressive Distributed Lag Model}

Following the panel unit root and co-integration tests, the panel ARDL model is estimated. The ARDL model recognizes short-and long-run coefficients and can be dependably utilized in short example periods. (Pesaran \& Shin, 1998) show that regardless of whether the example size is small, the long-run parameters are super-predictable while the short-run parameters are $\sqrt{\mathrm{T}}$ compatible. Therefore, equation (1) is transformed into the panel ARDL ( $p, q 1, q 2, q 3, q 4, q 5, q 6$,) model, where $p$ represents the lag of the dependent variable and $q$ means the lag of the independent variables. It is important to note that the variable BP (Balance of payment) was not lagged due to the presence of negative figures. Hence the Panel ARDL model is written as:

$$
\begin{gathered}
\operatorname{InFI}_{i t}=\theta_{i}+\sum_{j=1}^{p} \theta_{1, i j} \operatorname{InFI}_{i, t-j}+\sum_{j=0}^{q 1} \theta_{2, i j} \operatorname{In} Y_{i, t-j}+\sum_{j=0}^{q 2} \theta_{3, i j} \operatorname{InPPR} R_{i, t-j}+\sum_{j=0}^{q 3} \theta_{4, i j} \operatorname{InI}_{i, t-j}+ \\
\sum_{j=0}^{q 4} \theta_{5, i j} B P_{i, t-j}+\sum_{j=0}^{q 5} \theta_{6, i j} \operatorname{InE} L_{i, t-j}+\sum_{j=0}^{q 6} \theta_{7, i j} \operatorname{InEM} M_{i, t-j}+\varepsilon_{i t}
\end{gathered}
$$

Where $i=1,2, \ldots \mathrm{N}$ and $\mathrm{t}=1,2, \ldots \mathrm{T}, \theta_{i}$ constitute the fixed effects, $\theta_{1}-\theta_{8}$ is the lagged figure of the independent variables and the covariate and $\varepsilon_{i t}$ is the error term that is presumed to be white noise, and it differs across countries and time. Equation (4) considering the ECM is rewritten as 


$$
\begin{array}{r}
\operatorname{In} \Delta F I_{i t}=\theta_{i} \sum_{j=1}^{p} \theta_{1, i j} \operatorname{In}_{F} I_{i, t-j}+\sum_{j=0}^{q 1} \theta_{2, i j} \operatorname{In} \Delta Y_{i, t-j}+\sum_{j=0}^{q 2} \theta_{3, i j} \operatorname{In} \Delta P P R_{i, t-j}+\sum_{j=0}^{q 3} \theta_{4, i j} \operatorname{In} \Delta I_{i, t-j}+ \\
\sum_{j=0}^{q 4} \theta_{5, i j} \Delta B P_{i, t-j}+\sum_{j=0}^{q 5} \theta_{6, i j} \operatorname{In} \Delta E L_{i, t-j}+\sum_{j=0}^{q 6} \theta_{7, i j} \operatorname{In} \Delta E M_{i, t-j}+\delta_{1, i j} \operatorname{InFI}_{i, t-j}+\delta_{2, i j} \operatorname{In} Y_{i, t-j}+ \\
\delta_{3, i j} \operatorname{InPPR}_{i, t-j}+\delta_{4, i j} \operatorname{InI}_{i, t-j}+\delta_{5, i j} B P_{i, t-j}+\delta_{6, i j} \operatorname{InEL}_{i, t-j}+\delta_{7, i j} \operatorname{InEM}_{i, t-j}+\varepsilon_{i t}
\end{array}
$$

Where $\Delta$ is the first difference of variables. $\theta_{1}-\theta_{8}$ are the short-run coefficients, while $\delta_{1}-\delta_{8}$ are the long-run coefficients. Putting into account (Hendrys, 1995) recommendation, the short-run impact of fixed investment on growth is calculated by $\frac{\sum_{j=1}^{q 1} \theta_{2, i j}}{\left(1-\sum_{j=0}^{p} \theta_{1, i j}\right)}$.

Considering the fact that a long-run relationship is present between the dependent variable fixed investment and the regressors, the panel ECM model in equation (5) is rewritten as:

$$
\begin{aligned}
\operatorname{In} \Delta F I_{i t} & =\theta_{i}+\sum_{j=1}^{p} \theta_{1, i j} \operatorname{In} \Delta F I_{i, t-j}+\sum_{j=0}^{q 1} \theta_{2, i j} \operatorname{In} \Delta Y_{i, t-j}+\sum_{j=0}^{q 2} \theta_{3, i j} \operatorname{In} \Delta P P R_{i, t-j}+\sum_{j=0}^{q 3} \theta_{4, i j} \operatorname{In} \Delta I_{i, t-j} \\
& +\sum_{j=0}^{q 4} \theta_{5, i j} \Delta B P_{i, t-j}+\sum_{j=0}^{q 5} \theta_{6, i j} \operatorname{In} \Delta E L_{i, t-j}+\sum_{j=0}^{q 6} \theta_{7, i j} \operatorname{In} \Delta E M_{i, t-j}+\alpha_{i} E C M_{i, t-j}+\varepsilon_{i t}
\end{aligned}
$$

Where $\alpha_{i}$ represents the coefficient of the ECM that is tasked with measuring the speed of adjustment.

\subsubsection{Granger Causality Test}

The last step in this observational examination is to test for bi-directional causality between the dependent variable, fixed investment and the other variables. (Granger, 1969) hypothesized that in the event that the double-cross arrangement is cointegrated, at that point, there must be at any rate a unidirectional causality between them. This theory was adopted by (Dumitrescu \& Hurlin, 2012), but instead, he tried to identify causality in panel data. In that sense, the (Dumitrescu \& Hurlin, 2012) causality test is implored in this study. In order to test for the causality, a two-way Granger test is used as follows:

$$
\begin{gathered}
F I_{i, t}=\theta_{i}+\sum_{k=1}^{k} \vartheta_{i k} F I_{i, t-k}+\sum_{k=1}^{k} \pi_{i k} Y_{i, t-k}+\varepsilon_{i, t} \\
Y_{i, t}=\theta_{i}+\sum_{k=1}^{k} \vartheta_{i k} Y_{i, t-k}+\sum_{k=1}^{k} \pi_{i k} F I_{i, t-k}+\varepsilon_{i, t}
\end{gathered}
$$

With $i=1 \ldots, \mathrm{N}$ and $t=1 \ldots, \mathrm{T}$

Where $F I_{i, t}$ and $Y_{i, t}$ represent a Fixed investment and GDP for country $i$ in period $t$. The null hypothesis is written as:

$$
H_{0}=\pi_{i 1}=\cdots=\pi_{i k}=0 \forall i=1, \ldots, N
$$

If $N_{1}=0$ we can say that there exists causality for all coefficients in the panel. However, if $N_{1}>N$ then we can conclude that there is no causality for all the countries and thus $H_{1}$ becomes $H_{0}$. 


\section{Discussion of Results}

\subsection{Description of Statistics and Correlation Analysis}

The summary of the measurement results (Table 2) gives an elucidating measurement of the considered variables. The results show that the mean extends from -3.976 in the variable balance of payment to 193.014 from the variable Inflation. We can also see that balance of payment has the least figures while inflation has the most extreme figure. Taking into account the standard deviation, we can reason that the spread is sufficiently huge to investigate the interaction between the variables.

Table 1. Description of statistics and the correlation

\begin{tabular}{|c|c|c|c|c|c|c|c|}
\hline Variable & \multicolumn{2}{|l|}{ Mean } & Std. Dev. & \multicolumn{2}{|l|}{ Min } & \multicolumn{2}{|l|}{ Max } \\
\hline Fixed Investment & \multicolumn{2}{|l|}{25.516} & 11.796 & \multicolumn{2}{|l|}{5.186} & \multicolumn{2}{|l|}{79.145} \\
\hline GDP & \multicolumn{2}{|l|}{30.962} & 68.918 & \multicolumn{2}{|l|}{0.754} & \multicolumn{2}{|c|}{416.879} \\
\hline Purchasing Power & \multicolumn{2}{|l|}{94.1605} & 189.482 & \multicolumn{2}{|l|}{0.001} & \multicolumn{2}{|c|}{846.295} \\
\hline Inflation & \multicolumn{2}{|l|}{193.014} & 454.643 & \multicolumn{2}{|l|}{0.001} & \multicolumn{2}{|c|}{3234.84} \\
\hline Balance of Payment & \multicolumn{2}{|l|}{-3.976} & 10.629 & \multicolumn{2}{|l|}{-44.736} & \multicolumn{2}{|l|}{40.863} \\
\hline Electricity & \multicolumn{2}{|l|}{31.309} & 28.401 & \multicolumn{2}{|l|}{0.01} & \multicolumn{2}{|l|}{99.435} \\
\hline Unemployment rate & \multicolumn{2}{|l|}{43.9074} & 27.365 & \multicolumn{2}{|l|}{4.854} & \multicolumn{2}{|l|}{85.83} \\
\hline & InFI & InGDP & InPPR & InI & InBP & InEL & InEM \\
\hline InFl & 1.0000 & & & & & & \\
\hline InGDP & -0.1138 & 1.0000 & & & & & \\
\hline InPPR & -0.2249 & -0.0615 & 1.0000 & & & & \\
\hline InI & -0.2061 & -0.0159 & 0.5197 & 1.0000 & & & \\
\hline InBP & -0.2561 & 0.0528 & -0.1060 & 0.0142 & 1.0000 & & \\
\hline InEL & -0.1031 & 0.4420 & -0.2398 & -0.0708 & 0.2275 & 1.0000 & \\
\hline InEM & -0.1422 & 0.3188 & -0.4098 & -0.0080 & 0.4255 & 0.7282 & 1.0000 \\
\hline
\end{tabular}

We also perform the correlation analysis to ensure that there is no exact or linear dependence among the regressors to avoid multicollinearity. From the correlation table above, there is a low bivariate correlation among the regressors, and we deduce this from the simple fact that all the variables have a correlation of less than 0.8 . The regressors purchasing power parity rate and unemployment rate show the lowest correlation, and electricity and unemployment rate show the highest correlation.

\subsubsection{Diagnostics Test Results}

To ascertain the integrity of the ARDL model, its pertinence, and accuracy in policymaking, there is the need to consider its measurable properties by carrying out diagnostic tests. The embodiment of the diagnostic test is to look at the heteroscedasticity, serial correlation, normality, and specification error related to the model. 
Table 2. Diagnostics Test Results

\begin{tabular}{|l|l|l|}
\hline Test & Test Statistic & Probability \\
\hline Serial Correlation: & & \\
\hline Wooldridge Test & 13.056 & $0.004 * * *$ \\
\hline Specification Error: & & \\
\hline Ramsey RESET test & 2.18 & 0.122 \\
\hline Heteroscedasticity: & & \\
\hline Breusch- Pagan test/ Cook-Weisberg test & 22.05 & $0.001 * * *$ \\
\hline Normality: & & \\
\hline Doornik- Hansen test & 7291.439 & $0.000 * * *$ \\
\hline
\end{tabular}

The table above shows that the regressors are normally distributed, serially uncorrelated, and homoscedastic. The Wooldridge test with a test statistic of 13.056 shows that we cannot reject the null hypothesis of no serial correlation in the regressors. From the probability value of the Ramsey RESET test, we reject the null hypothesis of misspecification in the model. This simply means that the model we applied is accurately specified and lacks no omitted variable bias. The test statistic from the Doornik-Hansen test shows that the regressors are distributed normally. The Breusch-Pagan / Cook-Weisberg test gives evidence of the rejection of heteroscedasticity among the variables under scrutiny.

\subsubsection{Cross-sectional Reliance}

This study implores the CD test developed by (Persaran, 2004). The CD test is used to examine whether the variables under investigation have cross-sectional independence. The results from the $\mathrm{CD}$ test are presented in table 3. The null hypothesis is rejected for GDP, inflation, electricity, and unemployment rates because the p-values are significant at the $1 \%$ level. However, the variables fixed investment and balance of payment the null hypothesis cannot be rejected because they are not significant even at the $10 \%$ level. (Sarafidis et al. 2012) emphasize that weak cross-sectional dependence in the residues does not affect the first-order properties of standard panel data estimators. This is because mean-independence conditions are preserved when the error correction model is specified.

Table 3. CD test

\begin{tabular}{|l|l|l|l|l|l|l|l|}
\hline & InFI & InGDP & InPPR & InI & InBP & InEL & InEM \\
\hline CD Test & 1.368 & 38.806 & 44.4 & 45.006 & 0.708 & 29.857 & 17.669 \\
\hline P- Value & 0.171 & $0.000 * * *$ & $0.000 * * *$ & $0.000 * * *$ & 0.479 & $0.000 * * *$ & $0.000 * * *$ \\
\hline
\end{tabular}

Under the null hypothesis of cross-section independence, $\mathrm{CD} \sim \mathrm{N}(0,1)$. P-values close to zero indicate data are correlated across panel groups.

\subsubsection{Panel Unit Root Tests}

Panel stationarity tests are imperative when imploring the ARDL model because the order of integration should be strictly I (0) and I (1). This study sought the use of the traditional IPS 
and LLC first generation unit root tests proposed by (Im, Pesaran \& Shin 2003) and (Levin, Lin, Chu, 2002) due to the evidence of the presence of cross-sectional reliance from the CD test. The results from these panel unit root tests are presented in table 4 . We can deduce that all variables have an order of integration I (0) and I (0); hence they are suitable to run the ARDL model.

Table 4. Results from IPS and LLC panel unit root test

\begin{tabular}{|l|l|l|l|c|}
\hline Variable & \multicolumn{1}{|l|}{ IPS } & \multicolumn{1}{l|}{ LLC } \\
\hline & Leve & \multicolumn{1}{l|}{$\Delta$} & Level & $\Delta$ \\
\hline InFI & -2.378 & $-5.314 * * *$ & -1.474 & $-6.284 * * *$ \\
\hline InGDP & -1.659 & $-4.319 * * *$ & -0.034 & $-5.279 * * *$ \\
\hline InPPR & -2.047 & $-4.527 * * *$ & -1.619 & $-3.783 * * *$ \\
\hline InI & -1.784 & $-4.147 * * *$ & -3.812 & $-6.437 * * *$ \\
\hline InBP & -2.230 & $-5.4753 * * *$ & $-3.633 * * *$ & - \\
\hline InEL & $-3.716 * * *$ & - & -1.120 & $-6.741 * * *$ \\
\hline InEM & -2.3185 & $-4.989 * * *$ & -1.256 & $-6.331 * * *$ \\
\hline
\end{tabular}

Note: for all p-values $* * * 1 \%$ significant level, $* * 5 \%$ significant level and $* 10 \%$ significant level

\subsubsection{Pedroni Co-integration Test}

The result of the Pedroni co-integration test is shown in Table 5. There are seven unique measurements partitioned into the panel statistic and the group statistic. According to the results, we reject the null hypothesis at the panel and group statistic level because, in outright terms, these figures are more prominent than 2 . We, therefore, presume that the factors being examined have a co-integration relationship.

Table 5. Pedroni co-integration

\begin{tabular}{|l|l|}
\hline Test & T- statistic \\
\hline Panel v-statistic & -0.590 \\
\hline Panel rho-statistic & 0.810 \\
\hline Panel t-statistic & -3.88 \\
\hline Panel ADF statistic & -3.59 \\
\hline Group rho - statistic & 2.137 \\
\hline Group t-statistic & -3.71 \\
\hline Group ADF statistic & -2.582 \\
\hline
\end{tabular}

\subsection{Empirical Analysis of the Panel ARDL Regression Results}

Table 6 presents the results of the panel ARDL model. Based on the results from the Hausman test, the study used the Pooled Mean Group (PMG). It is the preferred method of 
estimation as it combines averaging and pooling.

Table 6. ARDL model

\begin{tabular}{|l|l|l|l|l|}
\hline Variable & Coef. & Std. Err. & $\mathrm{z}$ & $\mathrm{P}>|\mathrm{z}|$ \\
\hline Long run \\
\hline InGDP & 0.046 & 0.035 & 1.30 & 0.195 \\
\hline InPPR & -0.280 & 0.084 & -3.33 & $0.001 * * *$ \\
\hline InI & 0.055 & 0.017 & 3.24 & $0.000 * * *$ \\
\hline InBP & -0.037 & 0.066 & -0.56 & 0.578 \\
\hline InEL & -0.532 & 0.074 & -7.20 & $0.000 * * *$ \\
\hline InEM & 0.168 & 0.128 & 1.31 & 0.190 \\
\hline Short run & \multicolumn{5}{|l|}{} \\
\hline InGDP & -0.397 & 0.545 & -0.73 & 0.466 \\
\hline InPPR & 2.217 & 1.423 & 1.56 & 0.119 \\
\hline InI & -0.190 & 0.102 & -1.88 & $0.060 *$ \\
\hline InBP & -0.406 & 0.111 & -3.64 & $0.000 * * *$ \\
\hline InEL & -0.227 & 0.381 & -0.60 & 0.551 \\
\hline InEM & -0.856 & 0.651 & -1.31 & 0.189 \\
\hline ECT & -0.376 & 0.089 & -4.21 & $0.000^{* * *}$ \\
\hline Cons & 3.639 & 1.641 & 2.22 & $0.027 * *$ \\
\hline
\end{tabular}

Note: $* * *, * * *$ denotes the $1 \%, 5 \%$, and $10 \%$ significance levels respectively

The results from the ARDL model above show the short-run and long-run estimates, as well as the error correction term, stand error and the constant. We can see that in the long term, fixed investment and GDP have a positive relationship. A percent change in GDP is associated with a $4.6 \%$ increase in fixed investment; however, the effect is not statistically significant. In the short run estimate, there is a negative but insignificant relationship between GDP and fixed investment. The negative relationship between fixed investment and GDP is expected in the short term because it takes some time to mitigate the positive spillover effects of an investment in the economy. (Vojtovič, Klimaviciene, \&Pilinkiene, 2019) allude to how long-term investment is vital for economic advancement for developed economies. The result proves that the benefits of fixed investment are yielded over a long period rather than short periods. This means that governments with long term plans for their economies should consider taking fixed investments as a way to build a better future. The cost in the short term cannot be compared to the benefits that will be enjoyed later on by the economy as it becomes productive. However, (Stock \& Watson, 2016) contradicted this by showing how private fixed investment contributed to the short term rise of GDP in America.

The purchasing power rate is showing a significant negative relationship in the long run and a positive (insignificant) relationship in the short run. The lack of consistent fixed investment will eventually lead to insufficient cash flow, negatively affecting the currency. Even though not significant, the short-term relationship is very important in highlighting how keeping a 
consistent investment rate affects the currency as investment boosts the strength of the currency. If there is no adequate investment in the short run, the effects are felt in the future as the local currency's strength is lowered. Hence, investors will avoid countries that do not show adequate economic support, such as good policies to encourage consistent fixed investment, as their returns will be affected by the currency's strength. (Grigorian, 2019), in a study on Malaysia, also found similar conclusions.

Inflation remains a key factor in the growth of fixed investment. A percent change in inflation leads to a $5.5 \%$ increase in fixed investment in the long run. As favorable inflation is maintained, more investment flows this is something we have seen in the region. Countries have been struggling to keep a good inflation rate, and in turn, their investment rate has been very low. A negative relationship between fixed investment and inflation in the short term is not surprising either. Inflation, if not handled correctly, leads to uncertainty which normally drives out investment. (Mustafa, 2019) explained how low inflation was a pivotal factor in increasing economic growth in Sri Lanka.

The negative relationship between fixed investment and balance of payment in the long term as well as the short term indicates that an increase in investment leads to a decrease in the balance of payment, implying that funds are being used to boost the different avenues that arise due to the influx of investment. Also, (Lea, 2019) illustrated how despite an increase in economic growth, the balance payment continued to decrease in the UK.

Electricity and investment show a significant negative relationship in the long haul as well as in the short-haul as more economical projects surge due to the presence of more investment, electricity usage increases. Thus, resulting in a more interactive relationship between the two.

The short-term negative effect of fixed investment on the unemployment rate is understandable because in the short term, when there is an influx of investment in the country, many jobs are created, hence the hostile relationship with the unemployment rate. However, if there is uncertainty and policies that encourage investment, the unemployment rate will increase since investors do not invest long term in the given project (country). This explains the negative interaction that we see between the unemployment rate and fixed investment.

The error correction term shows a long-run co-integration relationship at the $1 \%$ level. Any deviations from the long-run equilibrium are corrected at a $38 \%$ rate.

\subsection{Granger Causality Test Results}

The results of the granger causality test are presented in Table 7 . We can see that at the $1 \%$ level, there is bi-directional causality between the variable, fixed investment and GDP. Unidirectional causation is evident from fixed investment to inflation, fixed investment to balance of payment, electricity to fixed investment, and fixed investment to the unemployment rate, respectively. 
Table 7. Results from Granger Causality Test

\begin{tabular}{|l|l|l|l|}
\hline Null Hypothesis & W-statistic & Zbar-statistic & P-value \\
\hline FI does not granger cause GDP & 2.782 & 4.543 & $0.000^{* * *}$ \\
\hline GDP does not granger cause FI & 2.078 & 2.750 & $0.006 * * *$ \\
\hline FI does not granger cause PPR & 1.464 & 1.825 & 0.237 \\
\hline PPR does not granger cause FI & 1.545 & 1.389 & 0.165 \\
\hline FI does not granger cause I & 3.363 & 6.025 & $0.000^{* * *}$ \\
\hline I does not granger cause FI & 1.499 & 1.272 & 0.203 \\
\hline FI does not granger cause BP & 1.835 & 2.128 & $0.033^{* *}$ \\
\hline BP does not granger cause FI & 1.353 & 0.901 & 0.367 \\
\hline FI does not granger cause EL & 1.120 & 0.306 & 0.759 \\
\hline EL does not granger cause FI & 2.285 & 3.276 & $0.001 * * *$ \\
\hline FI does not granger cause EM & 2.878 & 4.788 & $0.000 * * *$ \\
\hline EM does not granger cause FI & 0.740 & -0.663 & 0.507 \\
\hline
\end{tabular}

Note: $* * *, * * *$ denotes the rejection of the null hypothesis at the $1 \%, 5 \%$, and $10 \%$ significance levels respectively.

\section{Conclusion and Policy Implications}

The focal point of this study was to illustrate how fixed investment interact with other economic factors in the SADC region using annual data from 1992-2018. Our study deduces that fixed investment has a positive interaction with long-term growth and negative interaction in the short term. This is because the investment is expected to yield benefits in the long run. Therefore, there is a need to continuously invest in these assets to ensure that the benefits are sustainable and build a long-term economic foundation. For governments to use long-term plans for their economies, a fixed investment must be considered a preferred method or way to build a better future. Thus, if handled correctly, investment is one of the principal intermediaries of economic growth in the long run.

While governments expect to maintain high levels of investment, it must be known that the positive spillover in the short run leads to more employment, an influx of foreign currencies, and more money in circulation in the country. Power shortages among these countries is still a significant threat contrasting with economic development, even though our study indirectly show the significance of electricity (energy) in a region. Hence, for sustainable growth, we further suggest regional integration among member states in funding energy-related projects. On the other hand, results prove that a favorable inflation rate both in the long and short-run can attract investment in the region; we, therefore, recommend that introducing policies that promote investment will massively contribute to the economic growth in the SADC region.

Then again, as we considered domestic investments in the study, we strongly advocate for less reliance on foreign investment but encourage independence of economies, an element that has gained popularity among researchers due to its importance. In conclusion, we realize 
that for the region's main agenda towards an integrated industrial development where all countries benefit from this initiation to be achieved, governments need to exploit the regional synergies by ensuring flexibility among national industrial policies and strategies, thus beneficial for both the member states and the region, in the long run, where sustainable economic growth can be assured.

\section{References}

Afonso, A., \& St. Aubyn, M. (2018). Economic growth, public, and private investment returns in 17 OECD economies. Portuguese Economic Journal, 18, 47-65.

https://doi.org/10.1007/s10258-018-0143-7

Ali, K. H., Faki, S. M., \& Suleiman, S. H. (2018). Determinants of Foreign Direct Investment Inflows in Southern African Development Community (SADC) Member Countries. International Journal of Science and Business, 2(4), 616-623.

https://doi.org/10.5281/zenodo.1441190

Amir, Z. B. M., Zaman, T., \& Ali, M. A. (2012). The Macroeconomic Determinants of Investment: Empirical Evidence from Bangladesh. International Journal of Scientific \& Engineering Research, 3(9), 1-13.

Anwer, M. S., \& Sampath, R. K. (1999). Investment and economic growth. (No. 1840-2016-152256).

Baliyan, M., \& Jain, G. D. (2016). Determinants Of Saving and Investment of Households: A Study Of NCR. International Journal of Innovative Research and Advanced Studies, 3(7), 222-230.

Barro, R. J. (1991). Economic Growth in a Cross Section of Countries. The Quarterly Journal of Economics, 106(2), 407-443. https://doi.org/10.2307/2937943

Bayraktar, N. (2019). Effectiveness of public investment on growth in sub-Saharan Africa. Eurasian Economic Review, 9(4), 421-457. https://doi.org/10.1007/s40822-018-0119-Z

Bello, A. A., \& Osinubi, T. S. (2016). Infrastructure development and economic growth in sub-Saharan Africa. [Online] Available:

https://www.wider.unu.edu/sites/default/files/Events/PDF/Bello.pdf

Blomstrom, M. (1996). Is Fixed Investment the Key to Economic Growth. The Quarterly Journal of Economics, 111, 12. https://doi.org/10.2307/2946665

Carlos, A. A. G., \& Rowland, P. (2004). Determinants of Investment Flows into Emerging Markets. Determinants of Investment Flows into Emerging Markets. Banco de la República.

Cavallo, E., Eichengreen, B., \& Panizza, U. (2017). Can countries rely on foreign saving for investment and economic development? Review of World Economics, 154(2), 277-306.

https://doi.org/10.1007/s10290-017-0301-5

Dumitrescu, E.-I., \& Hurlin, C. (2012). Testing for Granger non-causality in heterogeneous panels. Economic modelling, 29(4), 1450-1460. 
https://doi.org/10.1016/j.econmod.2012.02.014

Encinas-Ferrer, C., \& Villegas-Zermeño, E. (2018). Investment and Economic Growth. In International Conference on Applied Economics. pp. 657-678.

https://doi.org/10.1007/978-3-319-70055-7_46

Grigorian, M. D. A. (2019). Nonresident Capital Flows and Volatility: Evidence from Malaysia's Local Currency Bond Market: International Monetary Fund.

https://doi.org/10.5089/9781484393161.001

Hendry, D. F. (1995). Dynamic econometrics: Oxford University Press on Demand. https://doi.org/10.1093/0198283164.001.0001

Kosma, O. (2015). Determinants of Investment Activity: the Case of Greece. Eurobank Research. Economy \& Markets, 9(7), 1-21.

Kwan, A. C. C., Wu, Y., \& Zhang, J. (1999). Fixed Investment and Economic Growth in China. Economics of Planning, 32(1), 67-79. https://doi.org/10.1023/A:1003424418042

Lea, R. (2019). The balance of payments data continue to disappoint. Arbuthnot Banking Group, 1.

Levin, A., Lin, C.-F., \& Chu, C.-S. J. (2002). Unit root tests in panel data: asymptotic and finite-sample properties. Journal of econometrics, 108(1), 1-24.

https://doi.org/10.1016/S0304-4076(01)00098-7

Mbulawa, S. (2015). Determinants of financial development in southern africa development community (sadc): Do institutions matter? European Journal of Accounting Auditing and Finance Research, 3(6), 39-62.

Mupimpila, C., \& Funjika, P. (2010). Growth and Regional Integration: The Case of the Southern African Development Community. Zambia Social Science Journal, 1(2), 158-174.

Mustafa, A. (2019). The relationship between foreign direct investment and inflation: econometric analysis and forecasts in the case of Sri Lanka. J. Journal of Politics and Law, 12(2), 44-52. https://doi.org/10.5539/jpl.v12n2p44

Mutambara, T. (2009). Regional transport challenges within the Southern African Development Community and their implications for economic integration and development. Journal of Contemporary African Studies, 27(4), 501-525.

https://doi.org/10.1080/02589000903399488

Nangpiire, C., Rodrigues, R. G., \& Adam, I. O. (2018). Ease of doing business and foreign direct investment inflow among Sub-Sahara African countries. International Journal of Business and Emerging Markets, 10(3), 289-303.

https://doi.org/10.1504/IJBEM.2018.093006

Nyarota, S., Kavila, W., \& Mupunga, N. (2012). Foreign direct investment (FDI) in southern african development community (SADC) countries. Paper Prepared for the Committee of the Central Bank Governors In SADC. Reserve Bank of Zimbabwe. 
Pedroni, P. (2004). Panel co-integration: asymptotic and finite sample properties of pooled time series tests with an application to the PPP hypothesis. Econometric theory, 20(3), 597-625. https://doi.org/10.1017/S0266466604203073

Pelinescu, E., \& Radulescu, M. (2009). The impact of foreign direct investment on the economic growth and countries' export potential. Romanian Journal of Economic Forecasting, 4(1), 153-169.

Pesaran, M. H. (2007). A simple panel unit root test in the presence of cross-section dependence. Journal of applied econometrics, 22(2), 265-312. https://doi.org/10.1002/jae.951

Pesaran, M. H., \& Shin, Y. (1998). An autoregressive distributed-lag modelling approach to co-integration analysis. Econometric Society Monographs, 31, 371-413.

https://doi.org/10.1017/CBO9781139052221.011

Pesaran, M. H., Shin, Y., \& Smith, R. (2001). Bounds testing approaches to the analysis of level relationships. Journal of Applied Econometrics, 16(3), 239-326.

https://doi.org/10.1002/jae.616

Pesaran, M. H., Shin, Y., \& Smith, R. J. (1999). Bounds Testing Approaches to the Alanysis of Long-run Relationships: University.

Pesaran, M. H., Shin, Y., \& Smith, R. J. (2001). Bounds testing approaches to the analysis of level relationships. Journal of applied econometrics, 16(3), 289-326.

https://doi.org/10.1002/jae.616

Pesaran, M., \& Shin, Y. (1995). An ARDL Approach to Cointegration Analysis.

Rabnawaz, A., \& Jafar, R. M. S. (2016). Impact of Public Investment on Economic Growth. Munich Personal RePEc Archive, 15. https://doi.org/10.2139/ssrn.2796368

Ruwaydah, A., \& Ushad, S. A. D. (2015). Effects of Stock Market Development on Economic Growth: The Case of SADC Countries. In Proceedings of the Third Middle East Conference on Global Business, Economics, Finance and Banking (ME15Dubai October Conference). [Online] Available: http://globalbizresearch.org/Dubai_Conference2015_Oct/pdf/DF501.pdf

Sarafidis, V., \& Wansbeek, T. (2012). Cross-Sectional Dependence in Panel Data Analysis. Econometric Reviews, 31(5), 483-531. https://doi.org/10.1080/07474938.2011.611458

Sharma, B., \& Abekah, J. (2007). Foreign Direct Investment and Economic Growth of Africa. Atlantic Economic Journal, 36(1), 117-118. https://doi.org/10.1007/s11293-007-9103-9

Stefanović, S. (2008). Analitical framework of fdi determinants: Implementation of the oli model. FACTA UNIVERSITATIS: Economics and Organization, 3, 239-249.

Stock, J. H., \& Watson, M. W. (2016). Why Has GDP Growth Been So Slow to Recover? Paper presented at the Federal Reserve Bank of Boston, 60th Economic Conference: The Elusive "Great" Recovery: Causes and Implications for Future Business Cycle Dynamics. [Online] Available:

https://www.bostonfed.org/-/media/Documents/economic/conf/great-recovery-2016/james-h- 
stock.pdf

Vanheukelom, J., \& Bertelsmann-Scott, T. (2016). The political economy of regional integration in Africa. The Southern African Development Community (SADC) Report. ECDPM, Brussels. [Online] Available: http://ecdpm.org/peria/sadc

Vinesh, S. R., Boopendra, S., \& Hemraze, D. (2014). Determinants of foreign direct investment in SADC: an empirical analysis. The Business \& Management Review, 4(4), 146.

Vojtovič, S., Klimaviciene, A., \& Pilinkiene, V. (2019). The linkages between economic growth and FDI in CEE countries. Ekonomický časopis (Journal of Economics), 67(3).

Willem Te Velde, D., Warner, M., \& Page, S. (2004). Growth and Investment in Sub-Saharan Africa: Case studies. FIRST FULL DRAFT. Commissioned by the Commission for Africa: Overseas Development Institute London.

Yang, J., \& Stone, R. A. (1985). Investment dependence, economic growth, and status in the world system: A test of "dependent development". Studies in Comparative International Development, 20(1), 98-120. https://doi.org/10.1007/BF02718320

\section{Copyright Disclaimer}

Copyright for this article is retained by the author(s), with first publication rights granted to the journal.

This is an open-access article distributed under the terms and conditions of the Creative Commons Attribution license (http://creativecommons.org/licenses/by/4.0/). 